\title{
INVESTIGATION OF THE CORROSION PROBLEM IN THE PIPELINE OF ENRICHED ALUMINA RECYCLE TO ALUMINIUM CELL
}

\author{
Mohamed Abdelfatah Doheim \\ Professor, Mining and Met. Eng. Department, Faculty of Eng. Assiut \\ University, Assiut, Egypt
}

Shemy Mohamed Ahmed

Professor, Mechanical Eng. Department, Assiut University, Assiut, Egypt

\author{
Yasser Mohamed Abdelrahman \\ M.Sc student, Engineer,Aluminium Company of Egypt \\ E-mail/ yasser_egyptalum2005@yahoo.com
}

(Received June 1, 2008 Accepted June 30, 2008)

In this work, the failure of pipeline used for recycling the enriched alumina to self-baked (Soderberg) cells is investigated; the study includes also the deterioration of pipeline that recycling the enriched alumina to pre-baked cells and that recycling fresh alumina. Systematic measurements for the loss in the pipeline -wall thickness with the time are carried out. The gaseous emissions from the cells and the characteristics of enriched alumina are analyzed. Based on the analyses and visual inspections, a corrosive- wear sequence was identified, for the failure of pipeline of Soderberg system. The scales formed on the pipe inner wall are easily destroyed by the alumina impact due to the weak adherence of such scales. This resulted in the exposure of the fresh steel surface to the highly corrosive environment that prevails inside the pipeline, which accelerates the corrosion of the metal. For the pipeline recycling enriched alumina of pre-baked system, hard and dense layers were formed, which were strictly adherent to substrate. The loss in the pipeline wall thickness of the fresh and pre-baked alumina pipelines is negligible compared to Soderberg enriched line (0.5 versus 5.0 $\mathrm{mm} /$ year); however, the operating conditions of the particles impact (velocity, particle size, flux) were close to each other in value. Therefore, the failure mode of pipeline in the Soderberg system is an erosioncorrosion process.

KEYWORDS: Erosion-corrosion, Pipeline failure, aluminium smelting cell , Gaseous emissions, Carbon steel.

\section{INTRODUCTION}

In the aluminium smelting technology there are two cell types, the Pre-baked and the self-baked (Soderberg cell) .The principal difference between them is the type of anode used. Soderberg technology uses a continuous anode which is delivered to the cell in the form of a paste, which bakes in the pot itself. Prebaked technology, on the 
other hand, uses multiple anode blocks in each cell. These anode blocks are pre-baked in a separate facility and then delivered to the cell.

Emissions of fluorides from the smelting process, in gaseous and particulate form, were earlier considered to be the most important pollutants from smelting. Modern control systems to remove and recycle fluorides through gas collection and wet/dry scrubbing systems have largely eliminated the problem. In Naga Hammadi Misr aluminium company the cell gases go through a dry cleaning stations to capture mainly HF gases and the particulate fluoride salts. In the cleaning stations, there are pipelines and storage vessels for handling fresh alumina and others for handling enriched reacted alumina before being recycled to the cells. Pneumatic transportation system is used for conveying the fresh and enriched alumina. The main reaction occurring between fresh alumina and gases is the chemisorption of HF on the alumina (enriched alumina) to form AlF3 [1]. It was observed that after about 6 months operation a severe damage arised in the enriched alumina lines for Soderberg cell gases. However, there was a mild damage in fresh alumina lines and the lines of prebaked system whether transport fresh or enriched alumina. This may be attributed to the high concentration of corrosive agents, detected in the Soderberg pipelines, which promote the deterioration of the steel pipe, mainly due to erosion - corrosion. Figure 1 shows the erosion -corrosion problem in the transportation line of Soderberg cells. In addition to that ,the corrosion product can be introduced to the cell bath, which may contaminate the purity of the aluminium products . This has a substantial effect on the aluminium industry profitability, since aluminium quality is a key aspect of the export market.

Despite the extensive work done in the past, there has been no clear understanding of erosion-corrosion interaction in the field condition. Hence, the aim of this work is to study erosion -corrosion due to abrasion and corrosive agents flowing in the pipelines. In order to achieve the research objectives, the thickness loss rate is measured at different locations of cross -sectional area and different conditions, the circulating constituents of pipes are analyzed, the gases of cells are analyzed and the effect of erosion-corrosion product on the aluminium purity is checked.

\section{EROSION-CORROSION}

Corrosion is a material degradation process which occurs due to chemical or electrochemical action, and erosion is a mechanical wear process (e.g. impact of solid particles) [2]. When these two processes act together the conjoint action of erosion and corrosion in aqueous is known as erosion-corrosion. This phenomenon is known to cause premature failure in the equipment used in engineering applications. In other words, the combined effect of erosion and corrosion can be significantly higher than the sum of the effects of the processes acting separately [2, 3, and 4]. This net effect is called synergism. As proposed by many researchers, this net effect is due to the enhancement of corrosion by erosion and/or enhancement of erosion by corrosion [5]. The wastage of material in erosion-corrosion process according to the mechanism of material loss is considered a contribution of electrochemical corrosion and mechanical erosion: 


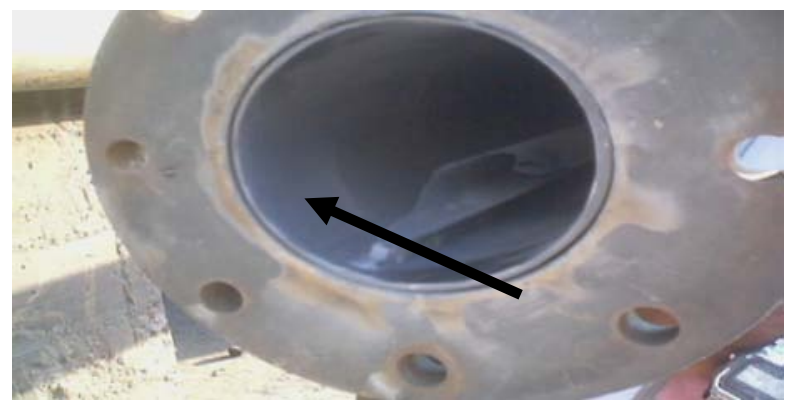

(a)

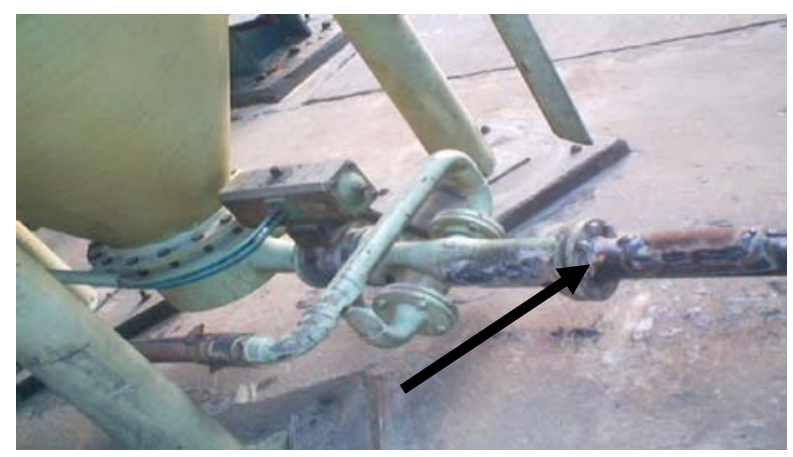

(b)

Fig. 1: Photographs of the erosion -corrosion in the pipeline of Soderberg cells; ainlet of the pipeline, b- failure of the inner pipe

$$
W_{t}=W_{c}+W_{e}
$$

Where:

$$
\begin{aligned}
& W_{c}=W_{c}^{0}+W_{c}^{e} \quad \text { And } \\
& W_{e}=W_{e}^{0}+W_{e}^{c}
\end{aligned}
$$

Where, $W_{t}$ is the total mass loss of the material, $W_{c}$ is the corrosion component with the presence of erosion, $W_{e}$ is the erosion component with the presence of corrosion, $W_{c}^{0}$ is the corrosion component free of erosion, $W_{e}^{0}$ is the erosion component free of corrosion, $W_{c}^{e}$ is the corrosion component promoted by erosion and $W_{e}^{c}$ is the erosion component enhanced by corrosion. 
The total material loss caused by erosion-enhanced corrosion and corrosion-enhanced erosion is often regarded as the wastage produced by the synergistic effect, $W_{s}$

$$
W_{s}=W_{c}^{e}+W_{e}^{c}
$$

In most cases, $\boldsymbol{W}_{s}$ is greater than zero because the mechanical erosion and electrochemical corrosion interact and accelerate each other concurrently. Such a synergistic effect leads to a dramatic increase in damage rate.

Although the problem caused by the interaction of erosion and corrosion is very serious, the mechanism of synergy is still not thoroughly understood because of its complexity. Postlethwaite [6] proposed that corrosion increases erosion rate by roughening the metal surface, because erosion rate is very sensitive to the impingement angle of solid particles. Li et al. [ 7 ] suggested a new mechanism that the localized attack at disruptions in the surface oxide (caused by the particle impacts ) enhances the rate of the crack growth , causes the flakes to become detached and then leads to higher erosion rate . Matsumura et al. [8] pointed out that erosion can be enhanced by corrosion through the elimination of the workhardened layer. Recently Malka et al. [9] have looked at whether erosion enhances corrosion and/or corrosion enhances erosion in pipe loop experiments on AISI 1018 carbon steel in 2 wt.\% silica sand ( $275 \mu \mathrm{m}$ ). They found that erosion enhances corrosion and corrosion enhances erosion but the dominant synergistic effect was that of corrosion on erosion.

\section{SYSTEM UNDER INVESTIGATION}

Associated with the EGYPTALUM pot lines there are gas treatment centers (GTC'S) that is positioned between the pot rooms to receive emissions from the pots. The GTC'S have the primary role of recycling the fluoride and dust captured from the pots. The emissions are treated in the GTC to extract the fluoride, using alumina as a scrubbing agent. The fluorinated alumina is then directed into the pots. Figure 2 shows the schematic of the pipeline network with the necessary storage bins and silos for one of GTC'S. The pipelines 5, 7 and 6, 8 are used for carrying enriched alumina and fresh alumina respectively. The pipeline material is carbon steel. The chemical analysis of the carbon steel is carried out by an optical emission spectrometry “ARL 3560" and is given in Table 1 . The pipeline has an inside diameter of $127 \mathrm{~mm}$ and thickness of $6 \mathrm{~mm}$. The pipeline length is $300 \mathrm{~m}$, in which $260 \mathrm{~m}$ is horizontal and $40 \mathrm{~m}$ is vertical. The pipeline consists of connecting tubes of $6 \mathrm{~m}$ long. The tube is seamless with flanged connections. In this study, the failure analysis is concerned with the horizontal pipeline. The air required for conveying the particulate material within the pipeline is jetting from small tube $20 \mathrm{~mm}$ diameter incorporated within the pipeline. The air velocity is measured by a pitot-tube meter which is already erected in the pipeline construction. The loss in thickness of the inner side of the pipe wall is investigated for pipelines 6,11,5 and 7.Pipeline 6 transports fresh alumina. Pipelines 11, 5 and 7 deals with enriched alumina. Pipeline 11 belongs to the prebaked system while pipelines 5 and 7 belong to the Soderberg system. The pipe wall thickness is measured by a 
portable ultrasonic thickness meter (DM2) having an accuracy of $0.1 \mathrm{~mm}$. The loss in thickness is the difference between the thickness before and after a definite period at the same location.

Table 1: Chemical composition of the pipeline material

\begin{tabular}{|c|c|c|c|c|c|c|c|c|}
\hline Element & $\mathrm{C}$ & $\mathrm{Mn}$ & $\mathrm{P}$ & $\mathrm{Si}$ & $\mathrm{Cu}$ & $\mathrm{Ni}$ & $\mathrm{Cr}$ & $\mathrm{Mo}$ \\
\hline wt \% & 0.08 & 0.55 & 0.007 & 0.018 & 0.019 & 0.023 & 0.025 & 0.008 \\
\hline
\end{tabular}

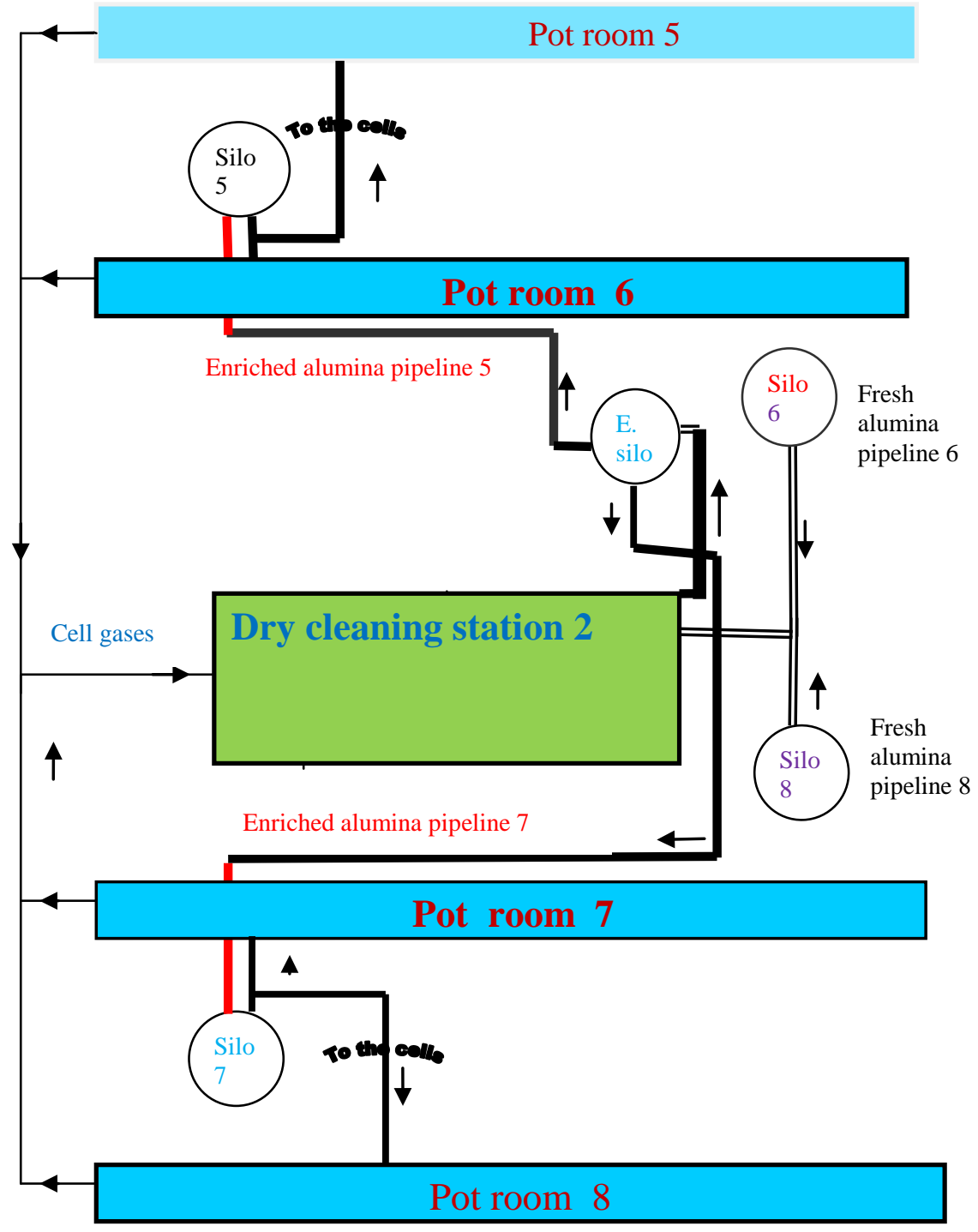

Fig.2: Schematic diagram for the Soderberg pipeline system 


\section{RESULTS}

\subsection{Measurements of the thickness loss rate}

The loss in the thickness of the inner side wall of horizontal pipelines is measured at three points. Two points (1\&2) at the ends of the horizontal diameter. The third one (3) at the bottom end of the vertical diameter. These measurements are repeated along the pipeline at a span of $60 \mathrm{~cm}$. Tables 2 and 3 show typical measurements for the loss in thickness along the circumferential and longitudinal tube wall, respectively .The data reported in Table 2 belong to pipeline 5 and those at Table 3 belong to pipeline 7 .From Table 2, it seems that the largest loss in the thickness is at the bottom (point 3). Therefore, the loss in the thickness at the bottom will be taken into consideration in analyzing the failure for different pipelines. Figure 3 and Table 3 show that the most deteriorated region is beside the flange.

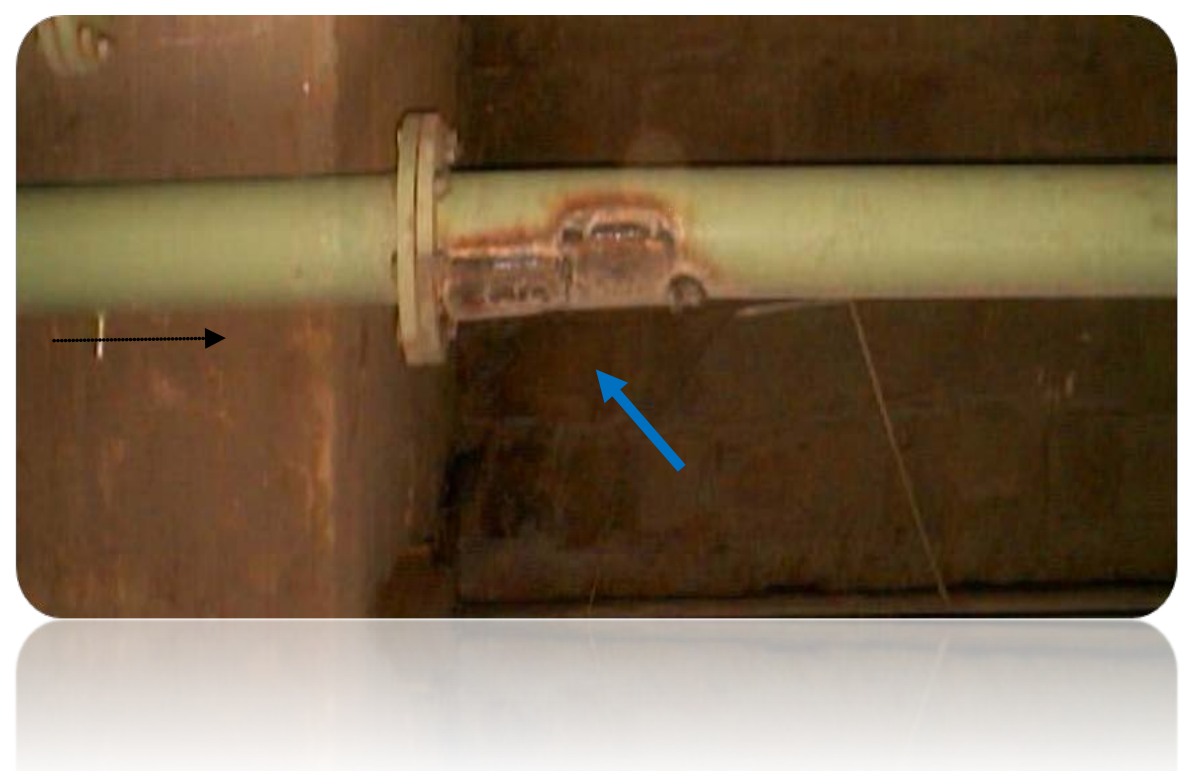

Fig. 3: Photograph of the more deteriorated locations

Table 2: Thickness loss distribution along circumferential tube wall

\begin{tabular}{|l|c|c|c|}
\hline Circumferential point & 1 & 2 & 3 \\
\hline Average loss ,mm/year* & 0.62 & 0.68 & 1.79 \\
\hline
\end{tabular}

(* averaged over 81 reading) 
Table 3: Thickness loss distribution along the tube wall length

\begin{tabular}{|l|l|l|l|l|l|l|l|l|l|}
\hline $\begin{array}{l}\text { Length apart } \\
\text { from flange, } \\
\mathrm{cm}\end{array}$ & 60 & 120 & 180 & 240 & 300 & 360 & 420 & 480 & 540 \\
\hline $\begin{array}{l}\text { Average loss, } \\
\text { mm/year }\end{array}$ & 2.07 & 1.85 & 1.91 & 1.87 & 1.84 & 1.99 & 1.92 & 1.85 & 1.91 \\
\hline
\end{tabular}

The loss and loss rate in the thickness for different pipelines working at different field conditions are shown in Table 4. The data presented in this Table are the average of $30 \sim 80$ measurements .It is clear from this Table that pipelines 5, 7 and 11 that transport enriched alumina have a higher loss rate than that transporting fresh alumina,i.e. pipeline 6 . However, the loss rate of pipeline 11, which belong to prebaked cells about $20 \%$ more than that of pipeline 6 . This means that the loss rate in the thickness of pipeline 6 and 11 is within the acceptable range and the erosion-corrosion effect is mild. The high rate for pipelines 5and 7 belongs to Soderberg cells. The loss is about 7-10 times that of pre-baked and fresh pipelines respectively .With regard to the effect of the velocity of air carrying the particulate material, the lower loss rate is the higher velocity, as shown in Table 4. It is presumed to occur the opposite, if the erosion is the dominant in the failure, since the erosion is an exponential function of the velocity. This interprets that the failure mechanism of the pipelines in the Soderberg system is different from that prevailed in the pipelines of the pre-baked system. The data of Table 4 indicate an increase in the loss rate by a decrease in air velocity, which may suggest different erosion mechanism at a low velocity.

\subsection{The effect of pipe wall degradation on the purity of molten aluminium.}

To illustrate the effect of pipe wall degradation on the purity of the aluminium product, the iron content of molten aluminium in two pot rooms is analyzed. The first pot room (NO.6) is fed by enriched alumina that is conveyed by highly degraded pipeline 5 of Soderberg system .However the second pot room (NO.4) is not fed by enriched alumina, so the pipe wall degradation conveyed to this pot room is very little or negligible. The iron content is measured every month and repeated along 9 months, as shown in Table 5 .The data indicate that the iron content in pot room (No. 6) is larger than that in pot room (No. 4). This reflects the deleterious effect of pipe wall degradation on the quality of the aluminium product.

\section{4 .3 Analysis of the scale formed on the inner pipeline wall}

To obtain general understanding of the severe damage encountered, preliminary analysis on samples collected from pipeline 11 (pre-baked system) and pipelines 5 and 7 (Soderberg system) are carried out. The qualitative analysis of the scales is carried out using a computer controlled diffractometer "D4 ENDEAVOR" and given in Table 
6. The quantitative analysis of scale of pipeline 11 is achieved by sequential computer X-ray fluorescent "SRS 3400". And found to be: $8.1 \mathrm{Na}$, 32.8Al, 8.4 F, 0.06 Si. The analyses of samples of pipeline 11 show that the main components are alumina and salts of cell bath components and not corrosion products. However, the analyses of scales collected from pipelines 5 and 7 illustrate that they are corrosion products.

Table 4: The loss and loss rate in thickness of different pipelines

\begin{tabular}{|c|c|c|c|c|c|c|c|}
\hline $\begin{array}{c}\text { Pipe } \\
\text { line }\end{array}$ & $\begin{array}{c}\text { Average } \\
\text { loss in } \\
\text { thickness,m } \\
\mathrm{m}\end{array}$ & $\begin{array}{c}\text { Nominal } \\
\text { operation } \\
\text { time, } \\
\text { months }\end{array}$ & $\begin{array}{c}\text { Actual } \\
\text { operation } \\
\text { time, month }\end{array}$ & $\begin{array}{c}\text { Thick. loss } \\
\text { rate, } \\
\mathrm{mm} / \text { year }\end{array}$ & $\begin{array}{c}\text { Velocity of } \\
\text { air, m/s }\end{array}$ & $\begin{array}{c}\text { Recycled } \\
\text { particulate }\end{array}$ & Cell type \\
\hline 6 & 0.6 & 30 & 16.25 & 0.44 & 49 & Fresh alumina & $\begin{array}{c}\text { Both } \\
\text { types }\end{array}$ \\
\hline 11 & 2.85 & 84 & 63 & 0.54 & 49 & $\begin{array}{c}\text { Enriched } \\
\text { alumina }\end{array}$ & Pre-baked \\
\hline 5 & 2.99 & 20 & 10.83 & 3.31 & 37 & $\begin{array}{c}\text { Enriched } \\
\text { alumina }\end{array}$ & Soderberg \\
\hline 7 & 2.8 & 12 & 6.5 & 5.16 & 31 & $\begin{array}{c}\text { Enriched } \\
\text { alumina }\end{array}$ & Soderberg \\
\hline 5 & 0.7 & 3 & 1.62 & 5.18 & 31 & $\begin{array}{c}\text { Enriched } \\
\text { alumina }\end{array}$ & Soderberg \\
\hline
\end{tabular}

Table 5: The iron content of molten aluminium, monthly measured, wt \%

\begin{tabular}{|l|l|r|r|r|r|r|r|r|r|r|}
\hline $\begin{array}{l}\text { Period } \\
\text { pot } \\
\text { rom }\end{array}$ & 1 & 2 & 3 & 4 & 5 & 6 & 7 & 8 & 9 & Av. \\
\hline $\begin{array}{l}\text { Pot } \\
\text { room } 6\end{array}$ & .175 & .170 & .229 & .178 & .197 & .239 & .220 & .208 & .187 & .200 \\
\hline $\begin{array}{l}\text { Pot } \\
\text { room 4 }\end{array}$ & .141 & .130 & .115 & .133 & .139 & .140 & 141 & .145 & .146 & .136 \\
\hline
\end{tabular}

Table 6: Analysis of the scale collected from pipelines

\begin{tabular}{|l|l|}
\hline Sample & Phases identified \\
\hline Scales of pipeline 11 & $\begin{array}{l}\text { Alumina }\left(\mathrm{Al}_{2} \mathrm{O}_{3}\right)-\mathrm{Cryolite}\left(\mathrm{NaF}-\mathrm{AlF}_{3}\right) \\
\text { Chiolit }\left(\mathrm{Na}_{5}-\mathrm{AlF}_{14}\right)\end{array}$ \\
\hline Scales of pipeline 5 & $\begin{array}{l}\text { Iron hydroxide }\left\{\left(\mathrm{Fe}(\mathrm{OH})_{3}\right\}\right. \\
\text { Iron oxide }\left\{\mathrm{Fe}_{2} \mathrm{O}_{3}-\mathrm{H}_{2} \mathrm{O}\right\}\end{array}$ \\
\hline
\end{tabular}




\section{Analysis of cell gases}

Aluminium cell exhaust gases contain particulates, such as dust and solidified cell content; tar; gases, such as $\mathrm{CO}_{2}, \mathrm{CO}, \mathrm{SO}_{2}$,etc. ; and some vaporized fluoride compounds and $\mathrm{H}_{2} \mathrm{O}$. The analysis of cell gases in the Soderberg and pre-baked systems are shown in Table 7. The Soderberg technology has higher emissions compared with that for pre-baked technology.

Table 7: Analysis of the species present in the fumes from smelting cells.

\begin{tabular}{|c|c|c|}
\hline System & Soderberg & Pre-baked \\
\hline Hydrogen fluoride, HF & $250 \mathrm{mg} / \mathrm{m}^{3}$ & $180 \mathrm{mg} / \mathrm{m}^{3}$ \\
\hline $\begin{array}{c}\text { Sulphur compounds } \\
\text { given as } \mathrm{SO}_{2}\end{array}$ & $400 \mathrm{mg} / \mathrm{m}^{3}$ & $34.5 \mathrm{mg} / \mathrm{m}^{3}$ \\
\hline Tar content & $100 \mathrm{mg} / \mathrm{m}^{3}$ & - \\
\hline Dust content & $2000 \mathrm{mg} / \mathrm{m}^{3}$ & $65 \mathrm{mg} / \mathrm{m}^{3}$ \\
\hline Water vapour & $10000 \mathrm{mg} / \mathrm{m}^{3}$ & - \\
\hline
\end{tabular}

\subsection{Alumina characterization}

The fresh alumina (Al2O3) has white color. However as result of passing the emission gases in the bed of fresh alumina for cleaning, the alumina has discolorated. The worst discolor was for the enriched alumina used in the Soderberg system. The color changed from white to cinnamon.

SEM photographs of the fresh alumina and the enriched alumina used in the pre-baked and Soderberg are shown in Fig.4. It is difficult to identify any change in the structure among the different alumina samples

The enriched and fresh alumina was analyzed to detect the components which may affect the pipe wall degradation. These analyses were carried out using X-RAY fluorescent (SRS 3400) and it is shown in Table 8. Loss on ignition (L.O.I) occurred between 300 and 1000 centigrade was the highest for enriched alumina used in Soderberg system. This higher moisture content manifests the increase in adsorption capacity in Soderberg [10].

\section{DISCUSSION}

From the results shown above, the loss in thickness of pipeline wall of Soderberg system was 7and 10 times that of pre-baked system and pipeline handling fresh alumina, respectively. The difference in operating conditions such as; velocity, size, and flux of particles is not much and can not be considered behind these results. 


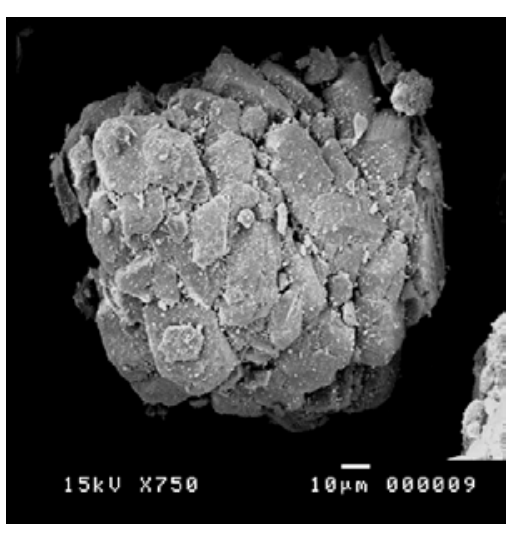

(a)

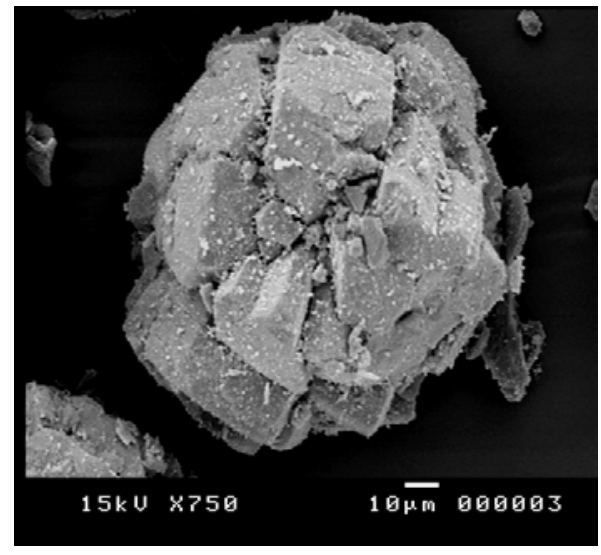

(b)

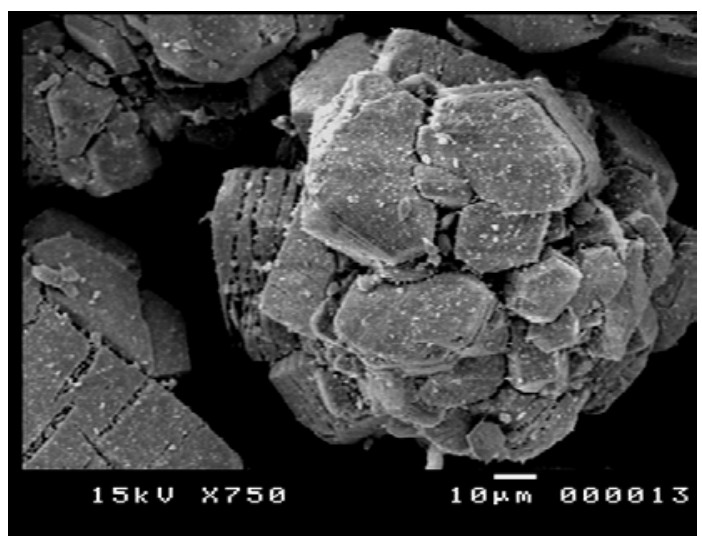

(c)

Fig.4: SEM photographs of the enriched alumina used in the Soderberg system (a), enriched alumina used in pre-baked system (b) and fresh alumina (c)

For pipelines of the pre-baked system, there is a resistance to the erosioncorrosion process because of the formation of protective cake layers. These layers are examined and found to be hard, dense and strictly adherent to the substrate. These layers are composed of salts of cell bath components; cryolite and chiolite as indicated in Table 7. These salts have been entrained with the cell gases as a vapor or particulate. It can be said that for the pipeline of pre-baked system, a negative synergy occurs, which is called an antagonistic effect [11].The reduction in corrosion rates $\left(-W_{e}^{c}\right)$ could result from the rapid coating growth on the pipeline wall.

The enhancement of erosion by corrosion occurred in pipelines of Soderberg system , might be attributed to the large amount of aggressive corrosive agents emitted from these cells (Table 8) . These gaseous emissions leave the cell and pass through ducting to an alumina dry scrubbing system. The alumina used in the dry scrubbers (enriched alumina) is recycled to the cells, along with any impurities and adsorbed 
gases collecting during scrubbing. The primary reason for dry scrubbing is to remove $\mathrm{HF}$, impurities (Fe, Ni, V) and particulate fluorides from electrolyte bath ( NaAlF4, Na3AlF6, Na5AlF14) [12]. However, as these emissions are efficiently captured in the dry scrubber, some attention has been focused on the emissions of lesser gases [13]. Capture of these other emissions can have downstream consequences on the alumina (see Table 8) from the dry scrubbers recycled into the cells [10].Inability to capture these emissions could become problematic.

Another reason for the encountered problem is the accumulation of enriched alumina on the pipelines during the stagnant period. This will accentuate the corrosion process especially at the bottom of the pipelines, as it is observed in Table.

Table (8): The analyses of enriched alumina and fresh alumina

\begin{tabular}{|c|c|c|c|c|}
\hline \multirow[b]{2}{*}{ Specification } & \multirow[b]{2}{*}{ Units } & \multicolumn{3}{|c|}{ Results } \\
\hline & & Soderberg & $\begin{array}{l}\text { Pre- } \\
\text { baked }\end{array}$ & Fresh \\
\hline $\mathrm{F}$ & $\%$ & 1.07 & 1.15 & - \\
\hline $\mathrm{S}$ & $\%$ & 0.17 & 0.21 & - \\
\hline $\mathrm{C}$ & $\%$ & 0.2 & 0.1 & - \\
\hline $\mathrm{SiO}_{2}$ & $\%$ & 0.005 & 0.005 & 0.008 \\
\hline $\mathrm{Fe}_{2} \mathrm{O}_{3}$ & $\%$ & 0.018 & 0.012 & 0.008 \\
\hline $\mathrm{Na}_{2} \mathrm{O}$ & $\%$ & 0.55 & 0.46 & 0.40 \\
\hline $\mathrm{CaO}$ & $\%$ & 0.05 & 0.04 & 0.32 \\
\hline Moisture(at $300 \mathrm{C}$ ) & $\%$ & 0.69 & 0.66 & 0.40 \\
\hline L.O.I (at 1000 C) & $\%$ & 2.2 & 1.6 & 0.87 \\
\hline Bulk density & $\mathrm{g} / \mathrm{cm}^{3}$ & 0.98 & 1 & 0.95 \\
\hline Angle of repose & degree & 30 & 30 & 33 \\
\hline $\begin{array}{l}\text { Sieve Analysis: } \\
+150 \text { micron } \\
\text {-45 micron }\end{array}$ & $\begin{array}{l}\% \\
\%\end{array}$ & $\begin{array}{l}1.61 \\
4.23\end{array}$ & $\begin{array}{l}5.64 \\
4.21\end{array}$ & $\begin{array}{l}5 \\
6\end{array}$ \\
\hline
\end{tabular}

\section{CONCLUSIONS}

1. The failure of pipeline recycling enriched alumina to Soderberg cells was due to erosion-corrosion. However, the dominant process was the effect of corrosion on erosion. 
2. The adsorbed gases on enriched alumina in Soderberg systems contains several corrosive agents, which accelerated corrosion.

3. In pipeline recycling enriched alumina to the pre-baked cell, rapid coating growth was formed on the pipeline wall. This could result in the reduction in corrosion rate.

4. The system design and operation need to be improved so that the erosion-corrosion problem can be controlled, e.g., the stagnant period, the cleaning of pipeline from the enriched alumina, the versatile change of air velocity,...etc

\section{REFERENCES}

[1] Grjotheim, K., and Kvande, H. "Introduction to aluminium electrolysis" $2^{\text {nd }}$ ed., Aluminium-verlag,Dtsseldorf,1993.

[2] Neville, A., and Hodgkiess, T., "Study of effect of liquid corrosivity in liquid-solid impingement on cast iron and austenitic stainless steel," British corrosion journal, 1997,32(3) ,p.197.

[3] Neville, A., Hodgkies T., and Dallas, J.T.,” A study of the erosion - corrosion behavior of engineering steels for marine pumping applications ,Wear 186187,1995,pp.497-505

[4] Burstein, G.T., Sasaki, K., " Effect of impact angle on the erosion-corrosion of 304L stainless steel,” Wear 186-187,1995,pp.80-94

[5] Zhou, S., Stack M.M.and Newman R.C.,"Characterization of synergistic effects between erosion and corrosion in an aqueous environment using electrochemical techniques, Corrosion sci, 1996,vol.12,p.934

[6] Postlethwaite, Effect of chromate inhibitor on the mechanical and electrochemical components of erosion-corrosion in aqueous slurries of sand , Corrosion,1981,Vol.37 No.1,p.1

[7] Li,Y., Burstein,G.T. and Hutchings,I.M.,” The influence of corrosion on erosion of Aluminium by aqueous silica slurries,Wear,1995, 186-187,p.515

[8] Matsumura,M., Oka,Y.,Hiura,H. and Yana,M., The role of passivating film in preventing slurry erosion-corrosion of austenitic stainless steel , ISIJ Int.,1991,31(2),p.186

[9] Malka ,R., Nesic,S. and Gulino,D.A., Erosion -corrosion and synergistic effect in distributed liquid - particle flow ,Wear,2007, 262,p.791.

[10] Hay,S.j., the formation and fate of carbonyl sulfide (COS) gas in aluminium smelting ,PhD thesis ,2002,Auckland ,Newzealand

[11] Wood,R.J.K., Tribo-corrosion of coating : a review, J. phys. D:Appl.phys., 2007,40,p.5502

[12] Grjotheim,K. and Welch,B.J., Aluminium smelter technology $2^{\text {nd }}$ ed.,1998,Dusseldorf : Aluminium-Verlag,p.328

[13] Keul,E.,Emission control. In the $13^{\text {th }}$ Int. course on process metallurgy of aluminium, 1994,Trandheim,Norway: ABB Environmental ,p.191 


\section{فحص مشكلة التآكل في خطوط أنابيب الالومينا المشبعة الراجعة إلى خلايا}

\section{الالومنيوم}

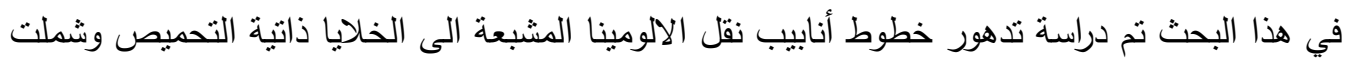

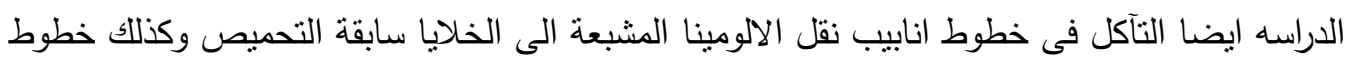

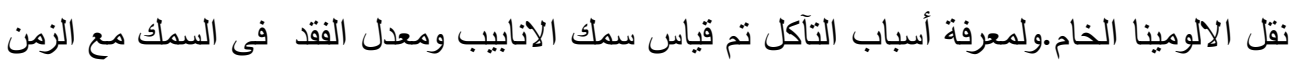
،وكذلك تم تحليل الغازات المنبعثة من الخلايا وكذلك الخواص الكيميائية و الفيزيائية للالومينا المشبعة

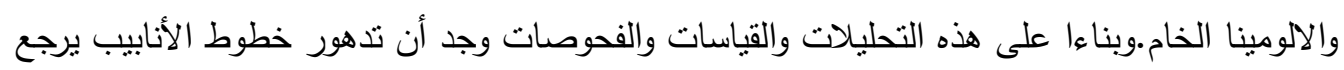

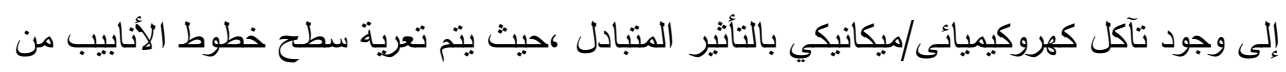

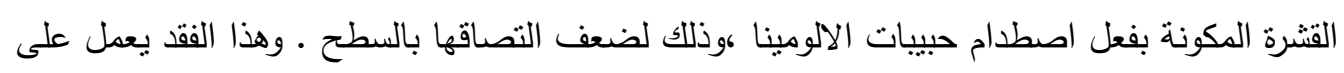

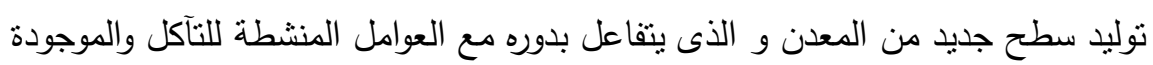

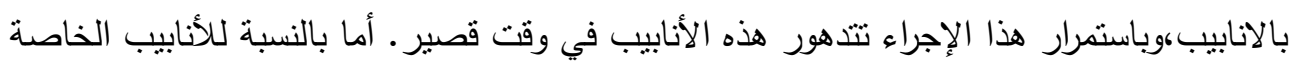

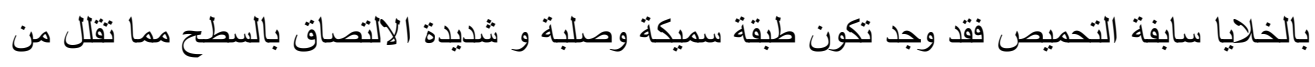
الفقد.فالققد فى كلا من خط انابيب الخلايا سابقة التحميص وخط لكابلة انابيب الالومينا الخام يكون مهملا بالمقارنة بخط أنابيب الخلايا ذاتية التحميص حيث تكون النسبة 0.5 مم/سنة مقابل 5مم/سنة رغم تتشابه ظروف الصدم من سرعة وحجم و نسبة تحميل الحبيبات،لذا فإن آلية التآكل فى خطوط أنابيب الخلايا ذاتية التحميص هي تآكل ميكانيكي - كهروكيميائى. 